PEMBELAJAR: Jurnal Ilmu Pendidikan, Keguruan, dan Pembelajaran

Volume 4 Nomor 2 Oktober 2020

e-ISSN: 2549-9114 dan p-ISSN: 2549-9203

(Received: April-2020; Reviewed: Agustus-2020; Published: Oktober-2020)

https://doi.org/10.26858/pembelajar.v4i2.13460

\title{
Studi Komparatif Kematangan Karir pada Mahasiswa Rumpun Sains \& Teknologi (Saintek) dan Sosial Humaniora (Soshum)
}

\author{
Ismeralda Putri Hasiani ${ }^{1}$, Anissa Lestari Kadiyono ${ }^{2}$, Erna Susiati ${ }^{3}$ \\ ${ }^{1}$ Universitas Padjadjaran, \\ ${ }^{2}$ Universitas Padjadjaran, \\ ${ }^{3}$ Universitas Padjadjaran
}

Corresponding e-mail: : aldahasiani@gmail.com; anissa.lestari@unpad.ac.id; erna.susiati@unpad.ac.id

\begin{abstract}
Abstrak: Penelitian ini bertujuan untuk membandingkan tingkat kematangan karir antara mahasiswa tingkat akhir rumpun Saintek dan Soshum. Penelitian ini menggunakan pendekatan non-eksperimental kuantitatif dengan metode studi komparatif. Penelitian dilakukan pada 408 responden yang terdiri dari 210 mahasiswa tingkat akhir rumpun Saintek dan 198 mahasiswa tingkat akhir rumpun Soshum di Universitas Negeri di Jawa Barat dengan teknik proportionate sampling. Pengambilan data dilakukan menggunakan kuesioner online, di mana kematangan karir diukur menggunakan alat ukur Career Development Inventory (CDI). Hasil penelitian menunjukkan bahwa: (1) tidak terdapat perbedaan; tingkat kematangan karir pada mahasiswa tingkat akhir rumpun Saintek dan Soshum; (2) tingkat kematangan karir yang dimiliki mayoritas berada pada kategori sedang/moderat. (3) dari dimensi pembentuknya, ditemukan terdapat perbedaan pada dimensi perencanaan karir antara mahasiswa tingkat akhir rumpun Saintek dan Soshum di Universitas Padjadjaran, dimana mahasiswa tingkat akhir rumpun Saintek memiliki perencanaan karir yang lebih tinggi dibandingkan mahasiswa tingkat akhir rumpun Soshum; (4) asal fakultas, usia, jenis kelamin, serta semester perkuliahan bukan merupakan faktor pembeda kematangan karir mahasiswa tingkat akhir rumpun Saintek dan Soshum.
\end{abstract}

Kata Kunci: kematangan karir, mahasiswa tingkat akhir, saintek, soshum

Abstract: This study aims to comparative career maturity between the final year student of natural science and social science in State University at West Java Province. The design of this study was non-experimental quantitative with comparative study methods. The study was conducted on 408 final year students, 210 final year students of natural science and 198 final year student of social science on Universitas Padjadjaran by taking a proportionate sampling. Retrieval of data using an online questionnaire distributed to final year students of natural science and social science. Career maturity was measured using Career Development Inventory (CDI). The result showed that (1) there was no difference in career maturity levels between final year students of natural science and social science; (2) both groups of the respondent having moderate career maturity levels; (3) there were significant differences in the planning dimensions of career maturity natural science on Universitas, where final year students of natural science had higher career planning compared to the final year students of the social science; (4) faculty, age, gender, and the semester of the study were not distinguishing factors.

Keywords: career maturity, final year student, natural science, social science

(C2020 -Ini adalah artikel dengan akses terbuka dibawah licenci CC BY-NC-4.0

(https://creativecommons.org/licenses/by-nc/4.0/) by penulis. 


\section{PENDAHULUAN}

Mahasiswa tingkat akhir merupakan calon sarjana yang diharapkan telah memiliki arah tujuannya dalam menjalankan kehidupannya setelah lulus. Mahasiswa tingkat akhir berada pada tahap eksplorasi karir karena berada pada rentang usia 15 - 24 tahun berdasarkan teori perkembangan karir dari Super (1957) yang artinya mahasiswa tingkat akhir seharusnya sudah membuat perencanaan karir, mencari informasi mengenai karir, dan juga membuat keputusan karir. Mengingat tuntutan karir pada seorang individu, Super (1957) menyatakan bahwa, untuk membuat pilihan karir yang tepat, seseorang harus menunjukkan tingkat kematangan karir tertentu (Coertse \& Schepers, 2004). Kematangan karir menurut Super (1990) adalah kesiapan individu untuk mengatasi tugastugas perkembangan karir dalam satu tahap perkembangan karir karena perkembangan biologis, sosial dan harapan masyarakat.

Pada mahasiswa tingkat akhir, individu dikatakan memiliki kematangan karir jika mereka mampu membuat pilihan keputusan karir dan jika mereka telah memperoleh pengetahuan tentang alternatif pendidikan dan pekerjaan (Coertse \& Schepers, 2004). Pada mahasiswa tingkat akhir Unpad pun terdapat permasalahan dimana proses pengambilan keputusan karir akan dilakukan terkait karir apa yang akan mereka tempuh selulusnya dari kuliah. Berdasarkan data dari Badan Pusat Statistik (BPS), jumlah tingkat pengangguran terbuka per Februari 2019 berjumlah 6,82 juta orang. dilihat dari tingkat pendidikannya, lulusan diploma dan universitas makin banyak yang tidak bekerja. Penyebab dari banyaknya lulusan diploma dan S1 yang menganggur adalah keterampilan yang tidak sesuai dengan kebutuhan. Hal ini tentu saja memberikan gambaran bahwa proses kematangan karir adalah hal yang krusial pada mahasiswa.

Pada Universitas Padjadjaran, terdapat kelompok studi Saintek dan Soshum. Saintek adalah ilmu yang mempelajari proses cara kerja alam untuk meningkatkan taraf hidup manusia menggunakan teknologi yang terdiri dari
Fakultas Kedokteran (FK), Fakultas Kedokteran Gigi (FKG), Fakultas Farmasi, Fakultas Psikologi (FAPSI), Fakultas Keperawatan (FKEP), Fakultas Geologi (FTG), Fakultas Matematika dan Ilmu Pengetahuan Alam (FMIPA), Fakultas Ilmu Perikanan (FPIK), Fakultas Pertanian (FAPERTA), Fakultas Peternakan (FAPET), dan Fakultas Teknik Ilmu Pertanian (FTIP), sedangkah Soshum adalah ilmu yang hubungan sosial, ekonomi, politik, dan budaya di masyarakat yang terdiri dari Fakultas Hukum (FH), Fakultas Ekonomi \& Bisnis (FEB), Fakultas Ilmu Budaya (FIB), Fakultas Ilmu Komunikasi (FIKOM), dan Fakultas Ilmu Sosial $\&$ Politik (FISIP).

Keduanya dipisahkan dalam Seleksi Bersama Masuk Perguruan Tinggi yang berbeda. Perbedaan tes seleksinya adalah mata pelajaran yang diujikan untuk rumpun Saintek meliputi biologi, fisika, kimia, dan matematika IPA, sedangkan untuk rumpun Soshum meliputi ekonomi, geografi, sejarah, dan sosiologi. Berdasarkan kondisi yang ada tersebut, maka menarik untuk diketahui apakah terdapat perbedaan kematangan karir pada Mahasiswa Saintek dan Soshum.

\subsection{Karir}

Karir didefinisikan sebagai kombinasi dan urutan peran yang dimainkan seseorang selama masa hidupnya (Super, 1980). Karir telah dipandang dengan berbagai cara sebagai urutan posisi yang dilakukan seseorang selama masa hidupnya (Super, 1957). Menurut Soetjipto, dkk (dalam Istiqomah, 2014), karir merupakan bagian dari perjalanan hidup seseorang, bahkan bagi sebagian orang, karir merupakan suatu tujuan hidup. Setiap orang memiliki hak dan kewajiban untuk sukses mencapai karir yang baik. Mengingat tuntutan karir pada seorang individu, Super (1957) menyatakan bahwa, untuk membuat pilihan karir yang tepat, seseorang harus menunjukkan tingkat kematangan karir tertentu (Coertse \& Schepers, 2004). 


\subsection{Teori Perkembangan Karir}

Teori perkembangan karir yang cukup terkemuka dan banyak digunakan adalah teori perkembangan karir oleh Super, yang menekankan pentingnya konsep diri dalam perkembangan karir dan melihat ekspresi dari pilihan pekerjaannya sebagai cerminan atau refleksi dari bagaimana seseorang tersebut melihat dirinya seperti halnya suatu ekspresi dari usaha mereka untuk menerapkan dan mengaktualisasikan konsep dirinya (Super, Starishevsky, Matlin, \& Joordaan, dalam Natalia, 2006). Teori Super (1957) mengemukakan bahwa terdapat lima tahap perkembangan karir, yaitu:

\section{Growth Stage}

Growth stage dimulai dari lahir hingga usia 15 tahun. Individu mulai sadar akan masa depan, meningkatkan kontrol pribadi atas kehidupan individu, meyakinkan diri untuk berhasil di sekolah dan juga pekerjaan, serta memperoleh sikap kerja dan nilai kerja yang kompeten.

2. Exploration Stage

Exploration stage dimulai dari usia 15 hingga 24 tahun. Tahap ini merupakan tahap untuk menguji diri, mencoba peran, dan pengeksplorasian pekerjaan melalui sekolah, aktivitas waktu luang dan kerja paruh waktu. Dengan kata lain, pada tahap ini individu mulai memikirkan berbagai alternatif karir. Akhir dari tahap ini adalah individu mulai permulaan pekerjaan penuh waktu.

3. Establishment Stage

Establishment stage dimulai dari usia 25 hingga 44 tahun. Pada tahap ini individu menstabilkan, mengkonsolidasikan, dan berkembang dalam posisi karir pilihannya.

\section{Maintenance Stage}

Maintenance stage dimulai dari usia 45 hingga 65 tahun. Tugas utama dari tahap ini adalah mempertahankan dan terus melakukan inovasi pada pekerjaan dan karir yang dittempuh.

5. Decline Stage

Decline stage merupakan tahap terakhir atau tahap kemunduran yang dimulai dari usia 65 tahun. Pada tahap ini, individu mengurangi aktivitas kerja dan memasuki masa pensiun.

\subsection{Kematangan Karir}

Kematangan karir adalah kesiapan
individu untuk mengatasi tugas-tugas
perkembangan karir dalam satu tahap
perkembangan karir karena perkembangan biologis, sosial dan harapan masyarakat (Super, dalam Super, Brown \& Brooks, 1990). Melihat pengembangan kejuruan sebagai proses seumur hidup, kematangan karir dapat didefinisikan sebagai sejauh mana seseorang telah menguasai tugas-tugas perkembangan yang sesuai dengan tahap karirnya (Hardin, Leong, dan Osipow, 2001).

Super mengemukakan bahwa terdapat lima dimensi kematangan karir (dalam Sharf, 2006), yaitu:

1. Planning, dimensi ini mengukur berapa banyak perhatian/pemikiran individu terhadap sejumlah aktivitas pencarian informasi dan berapa banyak penghayatan bahwa mereka memiliki pengetahuan tentang sejumlah aspek dalam pekerjaan.

2. Exploration, di dalamnya mencakup kemauan pelajar untuk menggunakan sumber daya yang ada, seperti orang tua, saudara, teman, dosen, konselor, internet, dan lain-lain untuk penyelidikan. Konsep dasar dari dimensi ini adalah kemauan individu untuk menggali atau mencari informasi.

3. World of work information, dimensi ini memiliki dua komponen dasar. Pertama, terkait dengan pengetahuan tentang pentingnya tugas-tugas perkembangan seperti kapan individu seharusnya mengeksplorasi minat dan kemampuan mereka, bagaimana individu mempelajari tentang sejumlah pekerjaan, dan alasan mengapa individu mengubah pekerjaannya. Kedua, menyangkut pengetahuan tentang kewajibankewajiban pekerjaan pada beberapa pekerjaan terpilih, dan sejumlah perilaku aplikasi kerja.

4. Decision making, yaitu kemampuan untuk menggunakan pengetahuan dan pemikiran untuk membuat perencanaan karir. 
5. Knowledge of preferred occupation, yaitu bagaimana individu memilih pekerjaan-pekerjaan yang akan ditekuni sesuai dengan minat dan kemampuannya (Ningsih, 2013).

\subsection{Faktor-faktor Kematangan Karir}

\author{
Menurut Rice (dalam Riady, 2014), \\ terdapat beberapa faktor yang dapat \\ mempengaruhi kematangan karir seseorang, \\ yaitu orang tua, teman sebaya, sosial ekonomi, \\ lingkungan, pandangan hidup, jenis kelamin, \\ intelegensi, bakat dan kemampuan khusus, serta \\ minat.
}

\subsection{Rumpun Ilmu}

\section{Sains dan Teknologi (Saintek)}

Stone (dalam Wibawa, 2012) menyebutkan bahwa Sains adalah kumpulan pengetahuan dan cara-cara untuk mendapatkan dan mempergunakan pengetahuan itu. Sementara itu, dalam artikel kompasiana.com (Desember, 2017), teknologi didefinisikan sebagai penerapan ilmu, khususnya pengetahuan ilmiah alam (natural science). Dikutip dari kompasiana.com (Desember, 2017), saintek didefinisikan sebagai sebuah ilmu pengetahuan yang mempelajari proses dan cara kerja alam untuk meningkatkan taraf kehidupan manusia.

\section{Sosial Humaniora (Soshum)}

Menurut Roucek dan Warren (dikutip dari kompasiana.com, 2017), sosial atau sosiologi adalah ilmu yang mempelajari hubungan antara manusia dalam kelompok-kelompok. Sedangkan humaniora, dalam Kamus Besar Bahasa Indonesia (KBBI), didefinisikan sebagai ilmu pengetahuan yang meliputi filsafat, hukum, sejarah, bahasa, sastra, seni, dan sebagainya. Sehingga, Soshum didefinisikan sebagai ilmu pengetahuan yang mempelajari hubungan antar manusia dimana memiliki tujuan untuk menjadikan manusia sebagai mahkluk yang beradab dan bermartabat (kompasiana.com, 2017).

\section{METODE}

\subsection{Jenis Peneltian}

Penelitian ini menggunakan pendekatan kuantitatif non-eksperimental dengan metode studi komparatif.

\subsection{Waktu dan Tempat Penelitian}

Penelitian ini diselenggarakan di salah satu Universitas Negeri di Jawa Barat. Terdapat 16 Fakultas yang terbagi atas kelompok Saintek sebanyak 11 fakultas, yaitu Fakultas Kedokteran (FK), Fakultas Kedokteran Gigi (FKG), Fakultas Farmasi, Fakultas Psikologi (FAPSI), Fakultas Keperawatan (FKEP), Fakultas Geologi (FTG), Fakultas Matematika dan Ilmu Pengetahuan Alam (FMIPA), Fakultas Ilmu Perikanan (FPIK), Fakultas Pertanian (FAPERTA), Fakultas Peternakan (FAPET), Fakultas Teknik Ilmu Pertanian (FTIP) dan 5 fakultas Soshum, yaitu Fakultas Hukum (FH), Fakultas Ekonomi \& Bisnis (FEB), Fakultas Ilmu Budaya (FIB), Fakultas Ilmu Komunikasi (FIKOM), Fakultas Ilmu Sosial \& Politik (FISIP). Keseluruhannya memiliki 9444 mahasiswa tingkat akhir.

\subsection{Populasi dan Sampel}

Populasi yang diteliti pada penelitian ini adalah mahasiswa Universitas Padjadjaran rumpun Saintek maupun Soshum yang berada pada tingkat akhir masa studi yaitu dari semester tujuh ke atas yang berjumlah 9444 dimana mahasiswa rumpun Saintek berjumlah 4547 dan Soshum berjumlah 4897. Sampel penelitian adalah 210 mahasiswa tingkat akhir rumpun Saintek dan 198 mahasiswa tingkat akhir rumpun Soshum di Universitas Padjadjaran dengan teknik pengambilan sampel proportionate sampling.

\subsection{Data, Instrumen, dan Teknik Pengumpulan Data}

Teknik pengumpulan data adalah kuesioner online melalui Google Form. Instrumen atau alat 
ukur yang digunakan adalah Career Development Inventory (CDI) yang telah diadaptasi oleh Juwita (2016). Validitas diperoleh melalui expert judgment. Reliabilitas yang diperoleh menunjukkan alat ukur kematangan karir dapat diandalkan. Selain alat ukur utama, dilakukan pengambilan data penunjang yang meliputi data demografi. Data demografi yang diambil dalam penelitian ini adalah usia, jenis kelamin, dan semester perkuliahan.

\subsection{Teknik Analisis Data}

Analisis uji beda dilakukan dengan menggunakan uji beda Mann-Whitney (data berdistribusi tidak normal) dan Independent Sample T-test (data berdistribusi normal) untuk dua kelompok dan menggunakan uji beda Anova (data berdistribusi normal) dan Kruskal Wallis (data berdistribusi tidak normal) untuk yang lebih dari dua kelompok. Tingkat kepercayaan yang digunakan adalah sebesar 95\% dengan kriteria tolak H0 jika Sig. <0.05. Data demografi juga diolah dengan uji beda.

\section{HASIL DAN PEMBAHASAN}

a. Data Demografi

Tabel 1 Data Demografi Responden

\begin{tabular}{llc}
\hline & \multicolumn{1}{c}{$\begin{array}{c}\text { Data } \\
\text { Partisipan }\end{array}$} & $\mathbf{n}(\%)$ \\
\hline Jenis & Perempuan & $282(69,1 \%)$ \\
Kelamin & Laki-laki & $126(30,9 \%)$ \\
\hline Semester & 7 & $254(62,3 \%)$ \\
\hline Rumpun & 9 & $154(37,7 \%)$ \\
\hline Studi & Saintek & $210(51,5 \%)$ \\
Fakultas & FAPhum & $198(48,5 \%)$ \\
& FAPET & $23(5,6 \%)$ \\
& FAPSI & $24(5,9 \%)$ \\
& FARMASI & $19(4,7 \%)$ \\
& FEB & $29(1,7 \%)$ \\
& FH & $32(7,1 \%)$ \\
& FIB & $42(10,3 \%)$ \\
& FIKOM & $51(12,5 \%)$ \\
& FISIP & $44(10,8 \%)$ \\
& FK & $17(4,2 \%)$ \\
& FKEP & $17(4,2 \%)$ \\
& FKG & $11(2,7 \%)$ \\
& FMIPA & $39(9,6 \%)$
\end{tabular}

\begin{tabular}{clc}
\hline & \multicolumn{1}{c}{$\begin{array}{c}\text { Data } \\
\text { Partisipan }\end{array}$} & $\mathbf{n}(\boldsymbol{\%})$ \\
\hline & FPIK & $21(5,1 \%)$ \\
& FTG & $12(2,9 \%)$ \\
& FTIP & $20(4,9 \%)$ \\
\hline Usia & 19 & $3(0,7 \%)$ \\
& 20 & $30(7,4 \%)$ \\
& 21 & $196(48,0 \%)$ \\
& 22 & $137(33,6 \%)$ \\
& 23 & $38(9,3 \%)$ \\
& 24 & $3(0,7 \%)$ \\
& 25 & $1(0,2 \%)$ \\
\hline & Total & $408(100,0 \%)$ \\
\hline
\end{tabular}

Mayoritas responden adalah mahasiswa semester 7 yaitu sebanyak 254 orang $(62,3 \%)$. Dari segi usia, mayoritas responden berusia 21 tahun (48\%). Berdasarkan jenis kelamin, mayoritas responden adalah perempuan $(69.1 \%)$. Berdasarkan rumpun studi, proporsi Saintek adalah sebesar $51.5 \%$ dan Soshum sebesar $48.5 \%$. Untuk proporsi perfakultasnya, terdapat perwakilan responden dari setiap fakultas, dengan Fikom sebagai penyumbang responden terbanyak sejumlah 51 orang $(12,5 \%)$.

b. Perbedaan Kematangan Karir antara Mahasiswa Rumpun Saintek dan Soshum

Tabel 2 Hasil Independent Samples T-Test Kematangan Karir

\begin{tabular}{lcccc}
\hline Rumpun & N & Mean & Pvalue & Simpulan \\
\hline Saintek & 210 & 127,99 & 0,164 & $\begin{array}{c}\mathrm{H}_{0} \\
\text { diterima }\end{array}$ \\
$\begin{array}{l}\text { Soshum } \\
\text { Total }\end{array}$ & 198 & 125,46 & & \\
\hline
\end{tabular}

Berdasarkan tabel di atas, diperoleh bahwa tidak terdapat perbedaan signifikan mengenai kematangan karir pada mahasiswa tingkat akhir rumpun Saintek dan Soshum Universitas Padjadjaran $(p$-value $=0.164)$. Hal ini sejalan dengan penelitian yang dilakukan oleh Ratnaningsih et al. (2016) mengenai perbedaan kematangan karir pada siswa SMK berdasarkan jurusan yang juga mendapatkan hasil yang sama, yaitu tidak terdapat perbedaan kematangan karir ditinjau dari jurusan peminatan. Tidak adanya perbedaan kematangan karir ditinjau dari jurusan mengindikasikan bahwa ada faktor lain yang turut berkontribusi pada tercapainya kematangan 
karir pada individu, dimungkinkan bahwa ada faktor internal lainnya yang dapat membedakan kematangan karir antar individu (Ratnaningsih et al., 2016). Asal Jurusan tidak mempengaruhi tingkat kematangan karir mahasiswa meski mengalami proses pendidikan yang berbeda dalam fakultas yang berbeda. Bila dilihat dari kategorisasinya, maka dapat diketahui bahwa pada mahasiswa rumpun Saintek, sebanyak 104 responden $(49,5 \%)$ berada pada kategori tinggi, 105 responden $(50 \%)$ pada kategori sedang, dan 1 responden $(0,5 \%)$ pada kategori rendah. Sedangkan dari mahasiswa rumpun Soshum, sebanyak 81 responden $(40,9 \%)$ berada pada kategori tinggi, 116 responden $(58,6 \%)$ pada kategori sedang, dan 1 responden $(0,5 \%)$ pada kategori rendah. Dengan demikian dapat dilihat bahwa mayoritas mahasiswa tingkat akhir rumpun Saintek dan Soshum di Universitas Padjadjaran memiliki tingkat kematangan karir sedang. Hal tersebut dikarenakan dari kelima dimensi pembentuk kematangan karir mahasiswa tingkat akhir rumpun Saintek dan Soshum, tiga diantaranya masih berada pada kategori sedang.

Ketiga dimensi tersebut adalah dimensi planning, decision making, dan world of work information. Sementara itu, untuk dua dimensi lainnya, yaitu exploration dan knowledge of preferred occupation mayoritas sudah berada pada kategori tinggi

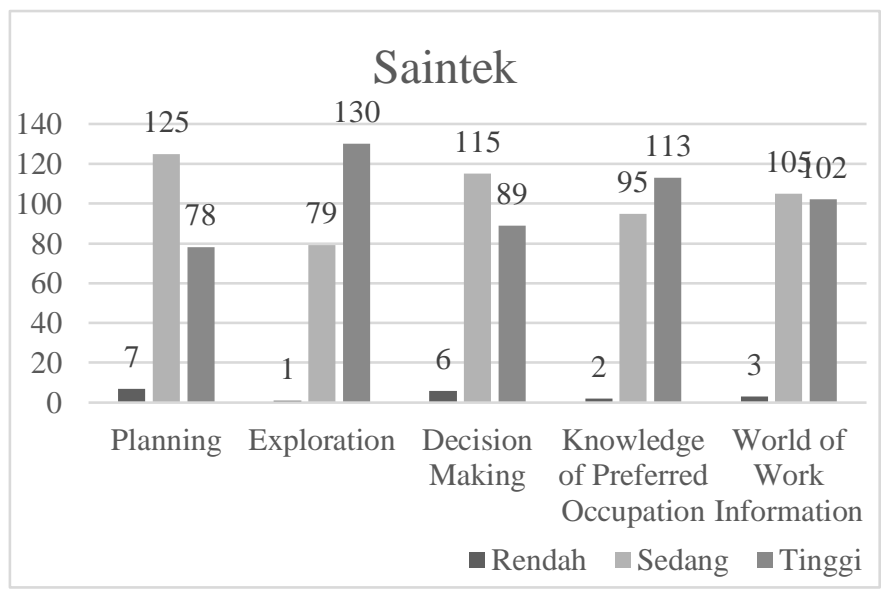

Gambar 1 Gambaran Dimensi Kematangan Karir Responden Saintek

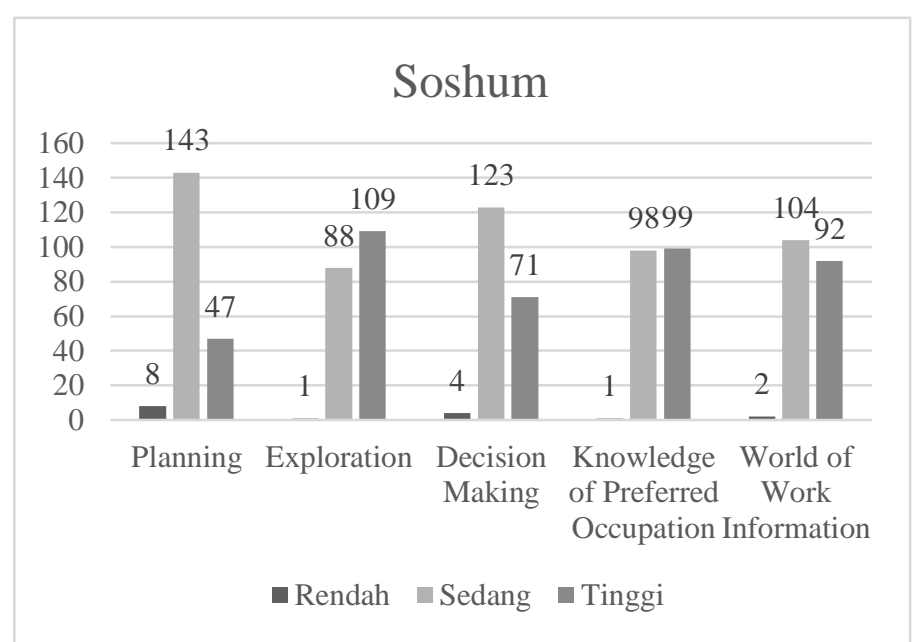

Gambar 2 Gambaran Dimensi Kematangan

Karir Responden Soshum

Tabel 3 Hasil Uji Beda Dimensi Kematangan

Karir antara Mahasiswa Rumpun Saintek dan Soshum

\begin{tabular}{|c|c|c|c|c|}
\hline Dimensi & Rumpun & Mean & \multicolumn{2}{|c|}{$\begin{array}{l}\text { Pvalue } \\
\text { Simpulan }\end{array}$} \\
\hline \multirow[b]{2}{*}{ Planning } & Saintek & 10,67 & \multirow[t]{2}{*}{0,014} & \multirow{2}{*}{$\begin{array}{c}\mathrm{H}_{0} \\
\text { ditolak }\end{array}$} \\
\hline & $\begin{array}{l}\text { Soshu } \\
\mathrm{m}\end{array}$ & 10,22 & & \\
\hline \multirow{2}{*}{$\begin{array}{c}\text { Explorati } \\
\text { on }\end{array}$} & Saintek & 34,94 & \multirow[t]{2}{*}{0,284} & \multirow{2}{*}{$\begin{array}{c}\mathrm{H}_{0} \\
\text { diterima }\end{array}$} \\
\hline & $\begin{array}{l}\text { Soshu } \\
\mathrm{m}\end{array}$ & 34,43 & & \\
\hline \multirow[b]{2}{*}{$\begin{array}{c}\text { Decision } \\
\text { Making }\end{array}$} & Saintek & 29,20 & \multirow[t]{2}{*}{0,168} & \multirow{2}{*}{$\begin{array}{c}\mathrm{H}_{0} \\
\text { diterima }\end{array}$} \\
\hline & $\begin{array}{l}\text { Soshu } \\
\text { m }\end{array}$ & 28,58 & & \\
\hline \multirow[b]{2}{*}{$\begin{array}{c}\text { Knowledg } \\
\text { e of } \\
\text { Preferred } \\
\text { Occupatio } \\
n\end{array}$} & Saintek & 34,35 & \multirow[t]{2}{*}{0,227} & \multirow{2}{*}{$\begin{array}{c}\mathrm{H}_{0} \\
\text { diterima }\end{array}$} \\
\hline & $\begin{array}{l}\text { Soshu } \\
\mathrm{m}\end{array}$ & 33,65 & & \\
\hline \multirow{2}{*}{$\begin{array}{l}\text { World of } \\
\text { Work } \\
\text { Informati } \\
\quad \text { on }\end{array}$} & Saintek & 18,81 & \multirow[t]{2}{*}{0,417} & \multirow{2}{*}{$\begin{array}{c}\mathrm{H}_{0} \\
\text { diterima }\end{array}$} \\
\hline & $\begin{array}{l}\text { Soshu } \\
\mathrm{m}\end{array}$ & 18,56 & & \\
\hline
\end{tabular}

Berdasarkan tabel di atas, diperoleh bahwa terdapat perbedaan pada dimensi planning pada kelompok mahasiswa tingkat akhir rumpun Saintek dan Soshum, dimana mahasiswa tingkat akhir rumpun Saintek lebih baik dalam perencanaan karir dibandingkan dengan mahasiswa tingkat akhir rumpun Soshum. Hasil 
tersebut sejalan dengan penelitian Niessen \& Peschar (2013) yang mengatakan bahwa siswa jurusan ekonomi lebih hedonistik dalam nilainilai pekerjaan mereka, oleh karena itu lebih kecil kemungkinannya siswa jurusan ekonomi untuk sampai pada keputusan karir. Hal tersebut mungkin menjadi salah satu faktor penyebab lebih rendahnya perencanaan karir pada mahasiswa rumpun Soshum. Fakultas-fakultas yang tergolong pada kelompok Saintek adalah Fakultas Kedokteran (FK), Fakultas Kedokteran Gigi (FKG), Fakultas Farmasi,

Fakultas Psikologi (FAPSI), Fakultas Keperawatan (FKEP), Fakultas Geologi (FTG), Fakultas Matematika dan Ilmu Pengetahuan Alam (FMIPA), Fakultas Ilmu Perikanan (FPIK), Fakultas Pertanian (FAPERTA), Fakultas Peternakan (FAPET), Fakultas Teknik Ilmu Pertanian (FTIP) dan lebih memiliki perencanaan karir. Hal yang mendorongnya adalah fakultas rumpun Saintek tersebut memiliki perhatian/pemikiran terhadap sejumlah aktivitas pencarian informasi dan memiliki penghayatan bahwa mereka memiliki pengetahuan tentang sejumlah aspek dalam pekerjaan.

Sedangkan untuk empat dimensi lainnya yaitu, exploration, knowledge of preferred occupation, decision making, dan world of work information tidak terdapat perbedaan pada kelompok mahasiswa tingkat akhir rumpun Saintek dan Soshum. Pada dimensi exploration, mayoritas responden berada pada kategori exploration tinggi menunjukkan bahwa mayoritas mahasiswa tingkat akhir rumpun Saintek maupun Soshum menilai dirinya sudah memahami makna karir, mengenal karir melalui pengalaman orang lain, dan sudah cukup memiliki informasi tentang sejumlah pekerjaan untuk memperdalam minat. Pada dimensi decision making, diperoleh mayoritas responden memiliki skor sedang, yang berarti mahasiswa tingkat akhir baik rumpun Saintek maupun Soshum menilai dirinya belum sepenuhnya dapat memahami cara mengambil keputusan dan individu belum sepenuhnya dapat mengambil keputusan sendiri.

Pada dimensi knowledge of preferred occupation, mayoritas responden memiliki skor tinggi, di mana hal ini berarti mayoritas responden menilai dirinya sudah memahami halhal yang penting bagi dirinya dan sudah memahami karakter diri yang dapat berkaitan dengan karir pilihannya. Terakhir, pada dimensi world of work information diperoleh bahwa mayoritas responden memiliki skor sedang. Hal ini menunjukkan bahwa mayoritas mahasiswa tingkat akhir rumpun Saintek maupun Soshum menilai dirinya belum sepenuhnya dapat mengetahui apa yang akan dicapai sehingga bertahan dengan pilihan karir dan melakukan tindakan untuk mencapai tujuan serta menunjukkan ketahanan untuk teralihkan dengan mencari informasi mengenai deskripsi berbagai pekerjaan ataupun tugas-tugas dari berbagai pekerjaan.

c. Perbedaan Kematangan Karir berdasarkan Demografi

Tabel 4. Hasil Uji Beda Kematangan Karir berdasarkan Demografi

\begin{tabular}{lll}
\hline \multicolumn{1}{c}{ Kategori } & Saintek & Soshum \\
Jenis Kelamin & p-value & p-value \\
\hline Laki-laki & & \\
\hline Perempuan & 0,153 & 0,881 \\
\hline Usia & & \\
\hline 19 & & \\
\hline 20 & 0,103 & 0,206 \\
\hline 21 & & \\
\hline 22 & & \\
\hline 23 & & \\
\hline 24 & & 0,270 \\
\hline Semester & & \\
\hline 7 & 0,632 & \\
\hline 9 & & \\
\hline
\end{tabular}

Berdasarkan Tabel 4 di atas, uji beda yang dilakukan menunjukkan bahwa tidak terdapat perbedaan tingkat kematangan karir berdasarkan jenis kelamin, usia, dan semester perkuliahan. Tidak terdapatnya perbedaan tingkat kematangan karir antara laki-laki dan perempuan pada mahasiswa tingkat akhir rumpun Saintek maupun Soshum sejalan dengan penelitian yang dilakukan oleh Nuswantoro (2013), yaitu tidak terdapat perbedaan kematangan perencanaan karir yang signifikan ditinjau dari jenis kelamin pada mahasiswa. Tekke dan Ghani (2013) dalam penelitiannya mengenai kematangan karir pada mahasiswa internasional juga menyatakan bahwa 
perbedaan kematangan karir berdasarkan jenis kelamin tidak terlalu kuat, yang berarti baik kedua jenis kelamin memiliki kesamaan dalam menyelaraskan keinginan dengan realitas dan memiliki pengetahuan yang sama untuk perencanaan karirnya (Jatmika, 2015).

Tidak terdapatnya perbedaan tingkat kematangan karir antara mahasiswa semester tujuh dan semester sembilan pada mahasiswa tingkat akhir rumpun Saintek maupun Soshum menunjukkan bahwa mahasiswa yang berada pada tingkat yang lebih tinggi atau lebih senior tidak lebih matang tingkat kematangan karirnya dibandingkan dengan mahasiswa yang berada pada tingkat yang dibawahnya atau juniornya.

Hal ini mungkin disebabkan karena mahasiswa semester tujuh dan semester sembilan sama-sama berada pada tingkat akhir perkuliahan dan berada pada tahap perkembangan karir yang sama yaitu exploration stage. Tidak terdapatnya perbedaan tingkat kematangan karir antara mahasiswa yang berusia 19, 20, 21, 22, 23, 24 dan 25 pada mahasiswa tingkat akhir rumpun Saintek maupun Soshum bertentangan dengan penelitian yang dilakukan oleh Naidoo (dalam Kerka, 1998) yang mengatakan bahwa makin bertambah usia sesorang, makin meningkat pula kematangan perencanaan karirnya.

Perbedaan hasil penelitian ini dengan penelitian sebelumnya mungkin terjadi dikarenakan rentang usia pada penelitian ini termasuk kedalam kategori rentang usia yang sama yaitu emerging adulthood. Berdasarkan Santrock (2014) individu pada emerging adulthood berada pada rentang usia 18 hingga 25 tahun. Rentang usia tersebut juga berada pada tahap perkembangan karir yang sama yaitu samasama pada tahap eksplorasi karir yang menjadikan tidak terdapatnya perbedaan pada rentang usia tersebut.

\section{KESIMPULAN}

Berdasarkan hasil penelitian yang telah dilakukan, maka dapat disimpulkan sebagai berikut:

- Tidak terdapat perbedaan signifikan antara mahasiswa tingkat akhir rumpun Saintek dan Soshum.
- Mahasiswa tingkat akhir rumpun Saintek maupun Soshum di secara umum berada pada kategori sedang atau cukup matang. Hal ini berarti mahasiswa tingkat akhir rumpun Saintek dan Soshum belum sepenuhnya dapat membuat dan menentukan keputusan karir.

- Terdapat perbedaan signifikan antara mahasiswa tingkat akhir rumpun Saintek dan Soshum pada dimensi planning, di mana mahasiswa tingkat akhir rumpun Saintek lebih baik dalam perencanaan karir dibandingkan dengan mahasiswa tingkat akhir rumpun Soshum.

- Penelitian ini tidak menemukan perbedaan signifikan dalam kematangan karir secara umum berdasarkan demografi, yaitu usia, jenis kelamin, dan semester perkuliahan di kelompok mahasiswa tingkat akhir rumpun Saintek dan Soshum.

\section{DAFTAR PUSTAKA}

Azis, I. (2018, April 11). Cara Cek Prodi PTN Favorit Berdasarkan Jurusan SMTA di SBMPTN 2018. Retrieved from https://tirto.id/cara-cek-prodi-ptn-favoritberdasarkan-jurusan-smta-di-sbmptn-2018cHBR

Coertse, S., \& Schepers, J. M. (2004). Some personality and cognitive correlates of career maturity. SA Journal of Industrial Psychology, 30(2), 56-73.

Dhia, N. (2017, Desember 10). Alasan Dibalik Berbedanya Karakter 'Orang' Saintek dan Soshum. Retrieved from https://www.kompasiana.com/nabiladhia/5a 274886fcf6811039478302/alasan-dibalikberbedanya-karakter-orang-saintek-dansoshum

Grashinta, A., Istiqomah, A. P., \& Wiroko, E. P. (2018). Pengaruh Future Time Perspective Terhadap Kematangan Karir Pada Mahasiswa. Jurnal Psikologi Pendidikan dan Konseling: Jurnal Kajian Psikologi 
Pendidikan dan Bimbingan Konseling, 4(1), 25-31.

Hardin, E. E., Leong, F. T., \& Osipow, S. H. (2001). Cultural relativity in the conceptualization of career maturity. Journal of Vocational Behavior, 58(1), 36-52.

Huda, A. K. (2019). Perbedaan Kematangan Karir Ditinjau Dari Jenis Kelamin dan Jurusan Pada Siswa. Character: Jurnal Penelitian Psikologi., 6(4).

Irmawati, B. R. (2018). Faktor-faktor yang mempengaruhi mahasiswa dalam memilih program studi di perguruan tinggi.

Istiqomah, I. (2014). Hubungan Antara Motivasi Belajar Dengan Perencanaan Karir Siswa Kelas VIII SMP Negri 3 Satu Atap Kedungjati.

Jatmika, D., \& Linda, L. (2017). Gambaran Kematangan Karir Pada Mahasiswa Tingkat Akhir. Psibernetika, 8(2).

Jawarneh, M. (2016). Career maturity among university students in Jordan: The case for social studies. Australian Journal of Career Development, 25(3), 110-116.

Juwita, V. A. (2016). Model Peran Dukungan Sosial: Orang Tua, Guru Bimbingan \& Konseling, dan Teman Sebaya Terhadap Kematangan Karir Pelajar Kelas XII SMAN di Kota Bandung. (Doctoral dissertation, Universitas Padjadjaran).

Kementrian Riset, Teknologi, Dan Pendidikan Tinggi Republik Indonesia (2017). Hasil Rekapitulasi Pendaftaran SBMPTN 2017.

Kerka, S. (1998). Career Development and Gender, Race, and Class. ERIC Digest No. 199.

Luzzo, D. A. (1995). Gender and Ethnic Differences in the Perception of Barriers to Career Development.

Natalia, K. D. (2006). Studi Mengenai Kematangan Karir Pada Mahasiswa Fakultas Psikologi dan Fakultas Hukum Universitas Padjadjaran.

Niessen, M., \& Peschar, J. (Eds.). (2013). Comparative research on education: overview, strategy and applications in eastern and western Europe. Elsevier.

Ningsih, D. A. (2013). Studi Komparasi Tentang Kematangan Karir Mahasiswa yang Mengikuti Magang dan Tidak Mengikuti Magang.
Nuraqmarina, F., \& Risnawati, E. (2018). Keputusan Pemilihan Karir: Studi Komparatif pada Siswa Remaja Jurusan IPA dan IPS. Psympathic: Jurnal Ilmiah Psikologi, 5(2), 231-240.

Nuswantoro, J. T. (2013). Perbedaan Kematangan Perencanaan Karir pada Mahasiswa Laki-laki dan Perempuan Ditinjau dari Keaktifan dalam Organisasi Kemahasiswaan. Character: Jurnal Penelitian Psikologi., 2(1).

Patnani, M. (2015). Upaya meningkatkan kemampuan problem solving pada mahasiswa. Journal Psikogenesis, 1(2), 130142.

Prideaux, L. A., \& Creed, P. A. (2001). Career maturity, career decision-making selfefficacy and career indecision: A review of the accrued evidence. Australian Journal of Career Development, 10(3), 7-12.

Pusparisa, Y. (2019, Mei 17). Angka Pengangguran Lulusan Universitas Meningkat. Retrieved from: https://katadata.co.id/infografik/2019/05/17/ angka-pengangguran-lulusan-perguruantinggi-meningkat

Ratnaningsih, I. Z., Kustanti, E. R., Prasetyo, A. R., \& Fauziah, N. (2016). Kematangan karier siswa SMK ditinjau dari jenis kelamin dan jurusan. Humanitas: Jurnal Psikologi Indonesia, 13(2), 112-121.

Ren, H. L. (2004). A study on career decisionmaking self-efficacy, career barriers and career choices congruence of graduate students (unpublished master thesis), Institute of Education at National Chiao Tung University, Hsinchu, Taiwan.

Renaldi, A. (2018, September 10). Melacak Penyebab Ribuan Sarjana Menganggur di Indonesia Tak Kunjung Dilirik Perusahaan. Retrieved from: https://www.vice.com/id_id/article/xwpqkn/ melacak-penyebab-ribuan-sarjanamenganggur-di-indonesia-tak-kunjungdilirik-perusahaan

Riady, M. A. (2014). Hubungan antara selfefficacy dengan kematangan karir pada siswa kelas XII SMK Ahmad Yani Jabung (Doctoral dissertation, Universitas Islan Negeri Maulana Malik Ibrahim). 
Santrock, J. W. (2014). A Topical Approach to Lifespan Development. New York: McGrawHill.

Sdg2030Indonesia.org. (2017). Tujuan SDG. Retrieved from: https://www.sdg2030indonesia.org/page/1tujuan-sdg

Septiana, N. N. A., Nurlita, F., \& Redhana, I. W. (2017). Komparasi Penggunaan Model Problem Solving dan Reasoning dengan Model Problem-based Learning Terhadap Hasil Belajar. Wahana Matematika dan Sains: Jurnal Matematika, Sains, dan Pembelajarannya, 11(1), 1-18.

Siegle, D. (2018). Educational Research Basics. (University of Connecticut).

Sharf, S. R. (2006). Applying Career Development Theory to Counseling. Canada: Thompson Wadsworth.

Shaughnessy, J. J., Zechmeister, E. B., \& Zechmeister, J. S. (2000). Research methods in psychology. McGraw-Hill.

Sugiyono, M. P. B. (2004). Metode Penelitian Kombinasi. Bandung: CV Alfabeta.

Sulistyo, B. (2015). Orientasi Karir Siswa Kelas II Jurusan Teknik Pemesinan di SMK Piri Sleman.

Sumayyah \& Hartiani, F. (2014). Hubungan Antara Autonomy dengan Kematangan Karir pada Perempuan Remaja Akhir dari Ibu yang Bekerja.

Super, D. E. (1957). The psychology of careers; an introduction to vocational development.

Super, D. E. (1983). Assessment in career guidance: Toward truly developmental counseling. The Personnel and Guidance Journal, 61(9), 555-562.

Super, D. E., Brown, D., \& Brooks, L. (1990). Career choice and development: Applying contemporary theories to practice.

Syarafina, N. A. (2017). Perbedaan Program Manajemen Berkarir Bank Swasta dan Bank Pemerintah untuk Pegawai yang Berlatar Belakang Akuntansi.

Taylor, K. M., \& Betz, N. E. (1983). Applications of self-efficacy theory to the understanding and treatment of career indecision. Journal of vocational behavior, 22(1), 63-81.
Tekke, M., \& Ghani, M. F. A. (2013). Examining the level of career maturity among Asian foreign students in Public University: gender and academic achievement. Hope Journal of Pakistan, 1(1), 101-121.

VandenBos, G. R. (2015). APA dictionary of psychology. 2nd eds. Washington, DC: APA.

Violina, E. I. (2017). Kematangan Karier Mahasiswa Tingkat Akhir Program Studi Bimbingan dan konseling Universitas Muhammadiyah Sumatera Utara. Jurnal Penelitian Bimbingan dan Konseling, 2(2).

Wibawa, F. C. (2012). Penerapan model pembelajaran fisika berbasis proyek untuk meningkatkan hasil belajar kognitif dan keterampilan berpikir kreatif(Doctoral dissertation, Universitas Pendidikan Indonesia).

Widyanuratikah, I. \& Saubani, A. (2018, Mei 8). Ini Jurusan Paling Favorit yang Dipilih Peserta SBMPTN. Retrieved from https://www.republika.co.id/berita/pendidika n/eduaction/18/05/08/p8ezpb409-inijurusan-paling-favorit-yang-dipilih-pesertasbmptn

Widyatama, T., \& Aslamawati, Y. (2015). Study Deskriptif Mengenai Kematangan Karir pada Mahasiswa Tingkat Akhir Fakultas Psikologi Unisba.

Wu. (2009). The relationship between parenting styles, career dicision self-efficacy, and career maturity of Asian American college students. (Dissertation). University of Southern California. 